\title{
Genetic code research: a precognition result (I)
}

\author{
Miloje M. Rakočević \\ University of Niš, Faculty of Sciences and Mathematics, Department of Chemistry, \\ Višegradska 33, 18000 Niš, Serbia
}

\begin{abstract}
This short communication reveals that the final result of my 40 years of research into the genetic code has the status of a precognition in the sense that it was seen in one of my dreams 75 years ago. The text published on my website (www.rakocevcode.rs) seven years ago, at a time when I could not know the final result, is attached as evidence [Key words: san i java]. At the same time, the idea is presented that both the result and its precognition could be in line with Jung-Pauli's hypothesis of synchronicity.
\end{abstract}

The final result of my 40-year research of the genetic code was announced in the previous paper (Rakočević, 2021, Surveys 1, 2 and 3). There are three specific systemarrangements of protein amino acids (AAs) - canonical amino acids - in the genetic code (GC). By crossing them, subsets of AAs are obtained, such that they are determined either by Gaussian number 51, or by Dürer's number 34 and its double value, the number 68 ; more precisely, by numbers $(51 \pm 20)$; [(34 \pm 10$)$; $(34 \pm 5)$; $(68 \pm 10)$; $(68 \pm 5)]$. When changes ("deviations") from the original numbers (51, 34 and 68) are taken as multiples of the number 5 and edited as in evidence-text, given here as Addendum, then it can be seen that there are grounds to talk about precognition:

$$
(1 \times 5),(2 \times 5),[(3 \times 5)],(4 \times 5),(5 \times 5)
$$

$5 \quad 10 \quad 20$

The distinctions are indicated as explained in the previous paper: 3 x 5 represents the determinant of symmetry of the Multiplication Table in the decimal number system (MMR, 2021, Table C2 in relation to Table C1), while 5 x 5 represents the zeroth position within a specific and significant system-arrangement (MMR, 2021, Table C3). [Arithmetical note: $(1-5=-4),(2-5=-3),(3-5=-2), 4-5=-1) ;(5-5= \pm 0) ;(6-5=$ $+1),(7-5=+2),(8-5=+3),(9-5=+4)$.]

The correspondence of the predictive telling (telling in a dream), indicated in Addendum in red, with the arrangement of the multiples of the number 5 given above, may be obvious if these tellings are commented, as follows.

When someone who "deals" with the Multiplication Table says 3 x $5=15$, then he is in himself (consciously or unconsciously) dealing with the uniqueness of the Multiplication Table in the decimal number system, in the area of symmetry. Later, during the research, he realized that this determinant for the octal number system would be $3 \times 4$, for the hexadecimal $3 \times 8$, etc. 
On the other hand, if someone says $(3 \times 5=15)$, plus 10 , is equal 25 , then it is "assumed" that 10 is $2 \times 5$, and that $1 \times 5$ is at the beginning of the whole sequence. Also it is assumed that between $(3 \times 5)$ and 25 is $(4 \times 5)$.

Box 1. The collaboration of Jung and Pauli in understanding of synchronicity

J Anal Psychol. 2004 Nov;49(5):707-28. doi: 10.1111/j.0021-8774.2004.00496.x.

Beyond synchronicity: the worldview of Carl Gustav Jung and Wolfgang Pauli Marialuisa Donati

Affiliations + expand

PMID: 15533199 DOI: $10.1111 / \mathrm{j} .0021-8774.2004 .00496 . \mathrm{x}$

\section{Abstract}

While exploring the phenomena of synchronicity, Carl Gustav Jung became acquainted with the quantum physicist Wolfgang Pauli and eventually began a collaboration with him. During that collaboration Jung's study of synchronistic phenomena underwent a considerable change; prior to the collaboration, Jung had stressed mainly the phenomenological and empirical features of synchronistic phenomena, while in association with Pauli, he focused his attention upon their ontological, archetypal character. Pauli, on the other hand, became increasingly sensitive to the philosophical aspects concerning the unconscious. Jung and Pauli's common reflections went far beyond psychology and physics, entering into the realm where the two areas meet in the philosophy of nature. In fact, as a consequence of their collaboration, synchronicity was transformed from an empirical concept into a fundamental explanatory-interpretative principle, which together with causality could possibly lead to a more complete worldview. Exploring the problematic character of the synchronicity concept has a heuristic value because it leads to the reconsideration of the philosophical issues that drove Jung and Pauli to clear up the conceptual background of their thoughts. Within the philosophical worldview arising from Jung and Pauli's discussions about synchronicity, there are many symbolic aspects that go against mainstream science and that represent a sort of criticism to some of the commonly held views of present day science.

\section{REFERENCES}

Atom and Archetype: The Pauli/Jung Letters, 1932-1958 - Updated Edition Paperback Abridged, July 21, 2014.

https://www.amazon.com/Atom-Archetype-Letters-1932-1958-Updated/dp/069116147X

Rakočević, M.M. (2017) Harmony of genetic code (Vol. 2), OSF Preprints DOI $\underline{10.31219 / \text { osf.io/89uah }}$

Rakočević, M.M. (2021) System-directed pairing of protein amino acids. Part I, OSF Preprints DOI $\underline{10.31219 / \text { osf.io/bpqzt }}$ 


\section{ADDENDUM}

The text was taken from the website www.rakocevcode.rs where it was published on October 4, 2014.

\section{TELLING BY A DREAM AND IN A DREAM - In the wake of Jung's synchronicity -}

\section{Prolog}

With a sense of shame, I admit that I found out about Jung's synchronicity only in 1996, at the age of 58. One day, that year, the phone rang and my friend Milivoj Tatic (philosopher, publicist, erudite and encyclopedist) answered, with whom I had not heard or seen for several years. In a long conversation, he also mentioned Jung's synchronicity, to which I asked him - what does that mean to him? "It is impossible that you not know that," he said, and promised to bring me a book about it at the first opportunity. Here is that book ("Interpretation of Nature and Psyche") and now with me. The authors are - the great name of psychology and psychiatry, Carl Gustav Jung, and - the great name of physics, Nobel laureate Wolfgang Pauli. The first half of the book is actually Jung's work: "Synchronicity: the principle of non-causal connection", and the second half, Pauli's work: "The influence of archetypal ideas on Kepler's scientific theories".

Jung's basic idea is that in nature, apart from causal (causal-consequential), there are also non-causal relations, in the sense that two or more phenomena take place simultaneously or in parallel, without being causally-consequentially connected. The first thing that was surprising to me on that occasion was the fact that I had just sent a scientific paper to a well-known international biological journal, about the genetic code, which in the title almost had the word synchronicity. (It will later be shown that this was my first paper on the genetic code, published in an international journal.) The title of my paper (written in collaboration with my colleague Anja Jokić, in English) read: "Four stereochemical types of protein amino acids: synchronic determination with chemical characteristics, atom and nucleon number" [Rakočević and Jokić, 1996].

I was shocked by the fact that I learned about the term synchronicity just at the moment after I had written a scientific paper in which I (almost unconsciously) dealt with the problem of synchronicity?! 


\section{Telling}

Back in 1946, I had just stepped into the eighth year of my life. One winter evening, on an evening village party, among other sleeping children, and awake adults, in a dream I uttered that prediction [precognitive] sentence: "three times five fifteen!", which in the morning, in the act of waking up (and not later) I was not aware, but my mother told me about it. I say precognitive, because the next day at school, the teacher didn't ask me anything but "How much is three times five?"

In the decades that followed, I did not pay special attention to dreams, nor to telling in a dream ${ }^{1}$, so I postponed indefinitely to read The dream of Djuro Koruga. ${ }^{2}$ As a boy, he dreamed that two suns in the sky "collided", ..., thunder broke, and he heard a precognitive sentence: "Carbon, 13; 18; 2 times 24; 2 turns into 3."

By the time I read this, I had already calculated earlier that the chemical element gold $(\mathrm{Au})$ is indeed in the position of the golden section, in the Periodic System of the Elements (PSE) ${ }^{3}$, and the "golden path" to gold largely leads through these "Djuro's numbers", and they prove to be characteristic determinants. Namely, if it is understood that hydrogen exists only in the seventh, and not in the first group of PSE, then carbon (the main builder of life), the sixth in the row (number 6 is the first perfect number), is also the first nonmetal, which "comes across", going from left to right in PSE. Numbers 13 and 18, respectively, are ordinal numbers of aluminium and argon, respectively; of the elements of the third period, which have $d$ orbitals (although they do not fill them): aluminium as the first such $p$ element, and aragon as the last such $p$ element. The

\footnotetext{
1 Books from the fields of psychology, neurology and psychiatry (especially Freud's), which I read intensively during 1962, while I was a soldier in the Yugoslav People's Army, probably contributed to that. (I read them out of interest, but also to make it easier to pass the time.) Among them was a book about dreams, by a certain Prohaska, if I remember the author's name well. And now I remember the basic thesis well. During the day, we think about something, says the author of that, of course, interesting book, so our thoughts are suddenly interrupted by some random event. During the next night, in a dream, our brain continues to complete the started thought in a new - picturesque and imaginative way. After that book I read, over the decades, all my dreams mostly came down to that mold. I would easily know, the next morning, after a night of sleep, which thought, from the day before, caused the dream.

${ }^{2}$ Here I will talk about all the events related to my reading about Djuro's dream presented in the book "Fullerene C60" (Koruga et al, 1993) (Of course, I will write if I can.) \{Additional Note (10. 05. 2021): "Djuro" and "Đuro" is the same in Serbian.\}

${ }^{3}$ I say really, because that was the hypothesis of Prof. Aleksandar Petrović, which I only confirmed. [About Prof. Petrović, cf. footnote 8 in (MMR, 2021).]
} 
element with ordinal number 24 is chromium, which is the first possible element with five half-filled $d$ orbitals (according to Hund's rule). ${ }^{4}$

This "decipherment" of Djuro's dream took place in the early 1990s, and that was the time when I was dealing with the problem of determining the genetic code with the golden mean and perfect numbers, so I was surprised to see that Djuro's numbers "hid" a third perfect number within themselves: 13 is actually number 4 , modulo $9(1+3$ $=4), 18$ is number $9(1+8=9)$, and number 24 is number $6(4+2=6)$; altogether, it is number 496 .

In those nineties, I also saw that there is a correspondence between three Djuro's and my three numbers: one simply needs to write the numbers one below the other, first the order of "my" numbers: 3, 5, 15, and below them write "Djuro's" numbers: $13,18,24$, in modular form, as $4,9,6$. After that we should add: $3+4=7 ; 5+$ $9=14 ; 15+6=21 ;$ all together, it is: $1 \times 7,2 \times 7,3 \times 7$.

These days (at the end of January 2014), in a conversation with Djuro, during a pleasant gathering, over lunch, we were reminded of everything I am writing about, and I additionally pointed out to him, as a novelty, that I recently saw that if number 4 multiplies numbers 1, 2, 3 and 4, then we are dealing with the so-called. The "golden whole" (my expression), which, altogether, "functions" in the genetic code. ... If this is so, then it makes sense to include multiplication by the number $4(4 \times 7=28)$ in the above multiplication account of the number seven (numbers 1,2 and 3$)^{5}$, which is a complement to the second perfect number.

Therefore, in Djuro's dream at the beginning we have "carbon", which is actually the number six, the first perfect number, and in the relation of his numbers to my numbers, we have the realization of the second perfect number; of course, we also have a third perfect number, as I have shown.

\footnotetext{
${ }^{4}$ The meaning of the phrase "2 times 24 " can be "deciphered" in two ways, both corresponding to significant divisive distinctions in PSE. The first way: in one "spatial" reading of numbers, the number "24" is at the same time the number "42", which is the position of the element molybdenum, an analogue of chromium, which is also the first element (in its period) with five half-filled $d$ orbitals. The second way of understanding the meaning of the phrase " 2 times 24 " is to understand that it is the number 48 . And that is the ordinal number of cadmium which is in the same period in which the $42 \mathrm{nd}$ element is molybdenum. They are also analogues, in the sense that molybdenum has a half-charge and cadmium a full charge orbital. In addition, cadmium has a distinct "limit" in that it also has the properties of not just the $d$ elements.

${ }^{5}$ The distinction $3 \times 7$ is also found in GK ("GC Floor Table" from 0 to 21; see the attached table) [Table D3 in (MMR, 2021]. The codon binary values $(U=0 ; C=1 ; A=2 ; G=3$ ) multiplied by the binary values of the positions $\left(2^{2}, 2^{1}, 2^{0}\right)$ give the required results. ... They are calculated as follows; for example, for GGG, like this: $(4 \times 3)+(2 \times 3)+(1 \times 3)=21$.
} 


\section{Between-telling}

In the mentioned nineties of the last century, I discovered the logic of the appearance of numbers in Djuro's dream as a correspondence with the positions of some distinct elements in PSE [Periodic system of elements]. I wondered, then, whether, perhaps, there was any logic in connection with the appearance of characteristic numbers in my dream; in fact, is this relationship between the numbers 3 , 5, and 15 perhaps the key determinant of the Multiplication table? The answer was positive, in the following sense: only by multiplying by 5 , we find ourselves in the area of symmetry (because 5 is half of 10 , and 10 is exactly the whole of the decade); by multiplying $1 \times 5$ we are on the decimal scale; with $2 \times 5$, we are still on the scale; only with $3 \times 5=15$ we "descend" from the scale. Hence, the $3 \times 5$ is a determinant of the Multiplication table in the decimal number system. ${ }^{6}$ Analogously, $3 \times 4$ is the determinant of the Multiplication table in the octal number system, $3 \times 8$ in the hexadecimal, and so on.

All this was known to me before the next (predictive?) event, which I will now describe. It has been exactly 52 years since I said "three times five - fifteen!" in my dream. That year, in 1998, my father was dying in the Leskovac hospital, and I stayed there, next to him - bed by bed - for about ten days. ... He came to consciousness from time to time, telling segments from his life; occasionally slept, and here, on one occasion, at the end of the day, it happened that in his sleep, in a state of sleep, he clearly uttered the following sentence: "Three times five fifteen and ten twenty-five" ?! I was more than amazed. At the same time, I experienced it as a great miracle, and as a critique. Criticism, in the sense that I saw that in determining the determinant of the Multiplication table, I did not take into account the ten that is on the measuring length of the decade. But, what is at stake here, whether it is about prognosis, synchronicity, or something else, I, at least for now, have no answer.

\section{Epilog u e}

On that day (January 30, 2014), during lunch, we asked together the question of the meaning of the final "section" in the number sequence of Djuro's dream: "Two becomes three". I remembered that even then, in the 1990s, I had some kind of explanation, which I could not remember now, and I did not think of anything else that

\footnotetext{
${ }^{6}$ This analysis helped me to see that Homer determined the number of verses of the lliad and the Odyssey by taking the starting $3 \times 5$ numbers from the geometric progression $2^{n}(2 \exp n)$ and from them, according to the key of mirror symmetry, two numbers to choose, one not to choose, two to choose, etc.), took those numbers whose sum will give exactly the sum of the number of verses in the two mentioned songs. But what was surprising was the knowledge that those numbers that Homer did not choose were chosen by Njegos, and, to be exact, he determined - the number of verses in Gorski vijenac, plus the number of scenes, plus the number of pages on which it was printed, etc. (see in my book "Njegoš's primordial logos", volume II, p. 189; compare the result 1741630, found in GK, then with Homer (p. 191 in this book), as well as with Njegoš (p. 60) [MMR, 2021, Boxes 13; 13.1-13.4.]
} 
could be a "solution". The only thing I could say is that it can be related to the factors of the first perfect number, the number $6: 2 \times 3$ is equal to 6 .

However, while we were sitting and chatting like that at lunch, I wondered if I could present my latest result on the genetic code to Djuro; so I gave up, it would be too much, and maybe I would spoil the pleasant atmosphere that reigned all the time. We parted, therefore, without discussing this new topic.

And, in my latest result, numbers (the number of atoms of the constituents of the genetic code) were found again, as important determinants. In short, the logical (and chemical) situation I dealt with in this most recent period of my (40-year) GC research was as follows: out of 64 codons, 61 have amino acid meaning, and therefore it makes sense to add exactly 61 codons for 61 amino acid molecule. \{Additional Note (10. 05. 2021): That 2014, I was talking about "40 years" of my research; now I repeat the same sentence. How? The thing is that in 1974 I applied for a master's thesis, and in 1981 I defended it and got my master's degree. Four years later, in 1985, I received my doctorate in biochemistry, so in 2025 I will talk again about my 40-year research.\}

I (but also other researchers) calculated a long time ago that the total number of atoms in 61 amino acid molecules (in their side chains) is exactly 594. If codons (64 code "words") are arranged according to the criterion of the third and not the second letter in the codon (as has been done exclusively so far), ${ }^{7}$ then the number 594 is "broken" into two parts. There are 288 atoms in the amino acid molecules on the left (pyrimidine) side of GC Table, and 306 atoms in those on the right (purine) side. [MMR, 2017, Table 3.5, p.10/51.]

It was necessary to understand now - what is the meaning of these numbers? In order to be able to do that, we had to start from the fact that there are really only 20 amino acid molecules in the genetic code, with 204 atoms in their side arrays; on the other hand, there are 192 nucleotides in 64 codons of the genetic code. ... All my attempts to come up with an answer to the question posed proved unsuccessful (and I didn't even know the answer the day we talked at that lunch), until I remembered Djuro's dream. The solution was then, by itself, stated: half the number of atoms $(1 / 2)$ in the basic set of amino acids is 102, and half the number of nucleotides (1/2) in the set of 64 codons is 96 . Well, now, if in these halves of "two passes into three", we get the number of atoms in the derived set of amino acids, because 96 thirds (1/3) of the number is 288, and 102 thirds (1/3) of the number 306.

After all that has been said, it makes sense to ask the question, what is the objective (scientific) meaning and reason for this 3: 2 ratio, regardless of Djuro's dream. On the one hand, it is the well-known limit of the golden ratio, ${ }^{8}$ which is realized

\footnotetext{
${ }^{7}$ In the "current" science of GC, it is considered that only the second and first positions in the codon have a coding function, while the third position is allegedly non-coding. If, however, GK is viewed as a system, which was already pre-biotic complete, then all three positions are coding. (Table GK, according to the criterion of the third letter, is given here ....) [MMR, 2017, Tab. 3.5, p. 10/51.]

${ }^{8}$ Moore, G.A. (1994) The limit of the Golden Numbers is 3/2. The Fibonacci Quartely, June-July, 211-217.
} 
precisely through that relationship (3:2). And the second is the ratio of these two numbers in a series of natural numbers. Namely, each follower of the number $n$ inevitably increases by the nth part of $\mathrm{n}$. Hence, only in the case of number 3 , the increase is correct for half of the predecessors, which, on the other hand, is a condition for "symmetry in the simplest case."

Miloje M. Rakočević

Given in Belgrade, on the Day of the Holy Martyr Kliment Ohridski, Summer of the Lord 2014, on February 5, Wednesday!

${ }^{9}$ Marcus, S (1989) Symmetry in the symplest case: the real line. Computers Math. Applic., 17, 103-115. 


\title{
Istraživanje genetskog koda: jedan prekognitivni rezultat (I)
}

\author{
Miloje M. Rakočević \\ Univerzitet u Nišu, Prirodno-matematički fakultet, Odsek za hemiju, \\ Višegradska 33, 18000 Niš, Srbija
}

\begin{abstract}
Apstrakt. U ovom kratkom saopštenju obelodanjuje se da finalni rezultat mojih 40-godišnjih istraživanja genetskog koda ima status prekognicije u tom smislu što je viđen u jednome mome snu pre 75 godina. Kao dokaz priložen je tekst objavljen na mome sajtu (www.rakocevcode.rs) pre sedam godina, u vreme kada za finalni rezultat nisam mogao znati [Ključne reči: san i java]. Istovremeno iznosi se ideja da bi oboje, rezultat i njegova prekognicija mogli biti u veyi sa JungPauli-jevom hipotezom o sinhronicitetu.
\end{abstract}

Finalni (skupni) rezultat mojih 40-godišnjih istraživanja genetskog koda saopšten je u prethodnom radu (Rakočević, 2021, Surveys 1, 2 and 3). Tu su predočena tri specifična system-aranžmana proteinskih amino kiselina (AAs) - kanonskih aminokiselina - u genetskom kodu (GC). Njihovim ukrštanjem dobijaju se podskupovi of AAs, takvi da su determinisani ili Gausovim brojem 51, ili Direrovim brojem 34, i njegovom dvostrukom

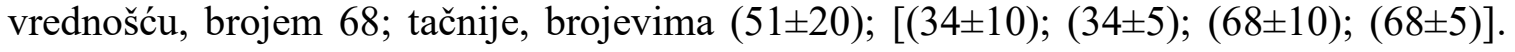
Kada se promene ("otkloni") od originalih vrednosti uzmu kao umnošci broja 5 i urede kao u mom tekstu-dokazu, datom ovde kao Dodatak, tada se vidi da o prekogniciji ima osnove govoriti:

$$
(1 \times 5),(2 \times 5),[(3 \times 5)],(4 \times 5),(5 \times 5)
$$

$5 \quad 10 \quad 20$

Distinkcije su naznačene tako kako je u prethodnom članku objašnjeno: 3 x 5 predstavlja determinantu simetrije Tablice množenja u dekadnom brojevnom sistemu (MMR, 2021, Tabela C2 u relaciji sa Tabelom C1), dok 5 x 5 predstavlja nultu poziciju unutar specifičnog i signifikantnog sistem-aranžmana (MMR, 2021, Tabela C3). [Aritmetička napomena: $(1-5=-4),(2-5=-3),(3-5=-2), 4-5=-1) ;(5-5= \pm 0) ;(6-5=+1),(7-5$ $=+2),(8-5=+3),(9-5=+4)$.]

Korespondencija predikcionih iskaza (izrečenih u snu), naznačenih u Dodatku crvenom bojom, sa gore datim aranžmanom umnožaka broja 5, može biti očigledna ako se ti iskazi prokomentariđu, kako sledi.

Kad neko ko se "bavi" Tablicom množenja kaže 3 x $5=15$, onda se on u sebi samom (svesno ili nesvesno) bavi unikatnošću Tablice množenja u dekadnom brojevnom 
sistemu, u području simetrije. Kasnije, tokom istraživanja, uviđa da će ta determinanta za oktalni brojevni sistem biti 3 x 4, za heksadekadni 3 × 8 itd.

S druge strane, ako neko kaže ( 3 x $5=15)$, plus 10 , jednako je 25 , onda se njemu "podrazumeva" da to 10 jeste $2 \times 5$, i da je ispred njega 1 x 5 . Takođe mu se podrazumeva da između (3 x 5) i 25 jeste $(4 \times 5)$.

DODATAK: Originalni tekst, prezet sa sajta www.rakocevcode.rs objavljen 4. octobra 2014. godine.

\section{KAZIVANJE SNOM I U SNU \\ - Na tragu Jungovog sinhroniciteta -}

\section{Prolog}

Sa osećanjem izvesnog stida, priznajem da sam za Jungov sinhronicitet saznao tek 1996, u svojoj 58. godini. Jednoga dana, te godine, zazvonio je telefon i javio se moj prijatelj Milivoj Tatić (filozof, publicista, erudita i enciklopedist), sa kojim se nisam bio čuo, ni video, tokom nekoliko godina. $U$ podužem razgovoru, pomenuo je i Jungov sinhronicitet na šta sam ga ja upitao - šta mu to znači? "Nemoguće je da to ne znaš", rekao je, i obećao da će mi, prvom prilikom, doneti knjigu o tome. Evo te knjige („Tumačenje prirode i psihe“) i sada kod mene. Autori su - veliko ime psihologije i psihijatrije, Karl Gustav Jung, i - veliko ime fizike, nobelovac Vorfgang Pauli. Prvu

polovinu knjige čini zapravo Jungov rad: „Sinhronicitet: načelo neuzročnog povezivanja“, a drugu polovinu, Paulijev rad: „Uticaj arhetipskih ideja na Keplerove naučne teorije“.

Osnovna Jungova ideja je ta da u prirodi, osim kauzalnih (uzročno-posledičnih), postoje i neuzročni odnosi, u smislu da se istovremeno, ili paralelno, odigravaju dve ili više pojava, a da međusobno nisu uzročno-posledično povezane. Prvo što je tom prilikom za mene bilo iznenađujuće, jeste činjenica da sam upravo bio poslao naučni rad jednom poznatom međunarodnom biološkom časopisu, o genetskom kodu, koji u naslovu, skoro da je imao reč sinhronicitet. (Kasnije će se pokazati da je to bio moj prvi rad o genetskom kodu, objavljen u međunarodnom časopisu.) Naslov tog mog rada (napisan u zajedništvu sa koleginicom Anjom Jokić, na engleskom) glasio je: „Četiri stereohemijska tipa proteinskih aminokiselina: sinhrona determinacija hemijskim karakteristikama, brojem atoma i nukleona“ [Rakočević and Jokić, 1996]. 
Mene je frapirala činjenica da ja za pojam sinhronicitet saznajem upravo u trenutku nakon što sam bio napisao naučni rad u kome se (skoro nesvesno) bavim problemom sinhroniciteta?!

\section{Kazivanje}

Te, sada daleke, 1946. godine, ja, Miloje Mirkov Rakočević, tek sam bio zakoračio u osmu godinu svog života. Jedne zimske večeri, na prelu, među drugom zaspalom decom, i budnim odraslim preljama, u snu sam izgovorio tu predikcionu [prekognitivnu] rečenicu: „Tri puta pet - petnaest!“, čega ujutru, u činu buđenja (a ni kasnije) nisam bio svestan, nego mi je majka o tome kazivala. Kažem predikcionu, jer me, sutradan u školi, učitelj ništa drugo nije pitao, nego jedino to: „Koliko je tri puta pet?“

U decenijama koje su usledile nisam obraćao naročitu pažnju na snove, niti na kazivanje u snu ${ }^{1}$, pa sam, na neodređeno vreme, odlagao da pročitam i San Đure Koruge. ${ }^{2}$ Kao dečak, on je sanjao kako su se dva sunca na nebu „sudarila“, ... , prolomila se grmljavina, i čula predikciona rečenicu: „Ugljenik, 13; 18; 2 puta 24; 2 prelazi u 3.“

$\mathrm{U}$ vreme kad sam ovo pročitao, već sam bio izračunao da se hemijski element zlato (Au) zaista nalazi u poziciji zlatnog preseka, u periodnom sistemu hemijskih elemenata (PSE) $)^{3}$, a „zlatni put“ do zlata, dobrim delom vodi upravo preko ovih „Đurinih“ brojeva, te se oni pokazuju kao karakteristične determinante. Naime, ako se shvati da se vodonik nalazi samo u sedmoj, a ne i u prvoj grupi PSE, onda je ugljenik (glavni graditelj života), šesti po redu (broj 6 je prvi savršeni broj), istovremeno i prvi nemetal, na koji se „naiđe“, idući s leva na desno u PSE. Brojevi 13 i 18, respektivno su redni brojevi aluminijuma i argona; elemenata treće periode, koji poseduju $d$ orbitale (iako ih ne popunjavaju): aluminijum kao prvi takav $p$ elemenat, a aragon kao poslednji

\footnotetext{
${ }^{1}$ Tome su, verovatno, doprinele i knjige iz oblasti psihologije, neurologije i psihijatrije (naročito Frojdove), koje sam intenzivno čitao, tokom 1962. godine, za vreme dok sam, kao vojnik, boravio u JNA. (Čitao sam ih iz zaainteresovanosti, ali i da bih lakše prekratio vreme.) Među njima je bila i jedna knjiga o snovima, izvesnog Prohaske, ako sam dobro zapamtio ime autora. I sada se dobro sećam osnovne teze. Preko dana razmišljamo o nečem, kaže autor te, svakako, zanimljive knjige, pa nam misao bude iznenada prekinuta nekim slučajnim događajem. Tokom sledeće noći, u snu, naš mozak nastavlja da, na neki novi - slikoviti i maštovit - način dovrši započetu misao. Nakon te pročitane knjige, tokom decenija, svi moji snovi uglavnom su se svodili na taj kalup. Lako bih, sutradan ujutru, nakon noći sa snom, odgonetnuo koje je to misli, iz prethodnog dana, rezultat.

${ }^{2}$ Ovde kazujem (u nekoj budućoj knjižici, ako budem stigao) o svim događanjima u vezi sa mojim čitanjem o Djurinom snu, u knjizi „Fuleren C60“ ...

${ }^{3}$ Kažem zaista , jer je to bila hipoteza prof. Aleksandra Petrovića, koju sam ja samo potvrdio ... [O prof. Petroviću takođe u fusnoti 8, u (MMR, 2021).]
} 
takav $p$ elemenat. Elemenat sa rednim brojem 24 je hrom, koji je prvi mogući elemenat sa pet polupopunjenih $d$ arbitala (po Hundovom pravilu). ${ }^{4}$

Ovo „odgonetanje“ Đurinog sna događalo se početkom devedesetih godina prošlog veka, a to je bilo vreme i kada sam se bavio problemom determinacije genetskog koda zlatnim presekom i savršenim brojevima, pa me iznenadilo kad sam uvideo da se u Đurinim brojevima „krije“ i treći savršeni broj: 13 je zapravo broj 4, po modulu $9(1+3=4), 18$ je broj $9(1+8=9)$, a broj 24 je broj $6(4+2=6)$; sve zajedno, to je broj 496.

Tih devedesetih godina uvideo sam i to da postoji korespodencija između tri Đurina i tri moja broja: jednostavno treba napisati brojeve jedan ispod drugog, i to najpre red „mojih“ brojeva: 3, 5, 15, a ispod njih napisati „Đurine“ brojeve: 13, 18, 24, u modularnoj formi, kao 4, 9, 6 . Nakon toga treba sabrati: $3+4=7 ; 5+9=14 ; 15+6=21$; sve zajedno, to je: $1 \times 7,2 \times 7,3 \times 7$.

Ovih dana (krajem januara 2014), u razgovoru sa Đurom, tokom jednog prijatnog druženja, za ručkom, podsetili smo se svega ovoga o čemu pišem, a dodatno sam mu, kao novost predočio, da sam nedavno uvideo da, ako se broj 4 množi brojevima 1, 2, 3 i 4, onda imamo posla sa tzv. „zlatnom celinom“ (moj izraz), što, sve zajedno, "funkcioniše" u genetskom kodu. ... Ako je to tako, onda ima smisla u gornji račun množenja broja sedam (brojevima 1,2 i 3$)^{5}$ uključiti i množenje brojem $4(4$ x $7=28$ ), što je dopuna do drugog savršenog broja.

Prema tome, u Đurinom snu na početku imamo „ugljenik“, što je zapravo broj šest, prvi savršeni broj, a u relaciji njegovih brojeva sa mojim brojevima, imamo realizaciju i drugog savršenog broja; naravno, imamo i treći savršeni broj, kako sam i pokazao.

\section{Međukazivanje}

Pomenutih devedesetih godina prošloga veka logiku pojavljivanja brojeva u Đurinom snu otkrio sam kao korespondenciju sa pozicijama nekih distinktnih elemenata u PSE. Pitao sam se, potom, da li, možda, postoji neka logika i u vezi sa pojavljivanjem karakterističnih brojeva u mome snu; zapravo, da li je ta veza između brojeva 3, 5 i 15,

\footnotetext{
${ }^{4}$ Smisao sintagme „2 puta 24 “ može se "odgonetnuti“ na dva načina, oba korespondentna sa značajnim razdeobnim distinkcijama u PSE. Prvi način: u jednom „prostornom“ čitanju brojeva, broj „24“ je istovremeno i broj "42", a to je pozicija elementa molibdena, analogona hroma, koji je takođe prvi elemenat (u svojoj periodi) sa pet polupopunjenih $d$ arbitala. Drugi način razumevanja smisla sintagme „2 puta $24^{\prime \prime}$ jeste da se shvati da je u pitanju broj 48. A to je redni broj kadmijuma koji se nalazi u istoj periodi u kojoj i 42-gi elemenat molibden. Oni su takođe analogoni, u tom smislu što molibden poseduje polupopunjenost, a kadmijum punu popunjenost $d$ orbitala. Osim toga, kadmijum poseduje i distinktnu "graničnost" time što on poseduje i svojstva $p$ a ne samo $d$ elementa.

${ }^{5}$ Distinkciju 3 x 7 nalazimo i u GK („Spratovna Tablica GK“ od 0 do 21; videti Tablicu u prilogu) [Tabela D3 u (MMR, 2021]. Binarne vrednosti kodona $(U=0 ; C=1 ; A=2 ; G=3$ ) pomnožene binarnim vrednostima pozicija $\left(2^{2}, 2^{1}, 2^{0}\right)$ daju tražene rezultate. ... Izračunvaju se tako, kako sledi; na primer, za GGG, ovako: (4 x $3)+(2 \times 3)+(1 \times 3)=21$.
} 
možda ključna determinanta tablice množenja? Odgovor je bio pozitivan, u sledećem smislu: tek množenjem sa 5 , nalazimo se u području simetrije (jer je 5 polovina od 10 , a 10 je upravo celina dekade); množenjem $1 \times 5$ mi se nalazimo na dekadnoj skali; sa $2 \times 5$, još uvek smo na skali; tek sa $3 \times 5=15$ „silazimo“ sa skale. Otuda je $3 \times 5$ determinanta tablice množenja u dekadnom brojevnom sistemu. ${ }^{6}$ Analogno, $3 \times 4$ je determinanta tablice množenja u oktalnom brojevnom sistemu, 3 x 8 u heksadekadnom itd.

Sve mi je to bilo poznato pre nastupanja sledećeg (predikcionog?) događaja, koji ću sada opisati. Bilo je prošlo tačno 52 godine od onog mog kazivanja u snu. Te, 1998 godine, moj otac je bio na samrti, u leskovačkoj bolnici, a ja sam tu, pored njega, boravio - krevet do kreveta - čitavih desetak dana. ... Povremeno je dolazio svesti, kazivao segmente iz svog života; povremeno spavao, a eto, jednom prilikom, u smiraju dana, dogodilo se i to da je u snu, u stanju spavanja, razgovetno izgovorio sledeću rečenicu: „Tri puta pet petnaest i deset dvadeset i pet“?! Bio sam više nego zaprepašćen. U isto vreme doživeo sam to kao veliko čudo, i kao kritiku. Kritiku, u tom smislu, što sam uvideo, da kod mog određivanja determinante tablice množenja, nisam uzeo u obzir i ono deset što se nalazi na mernoj duži dekade. Ali, šta je ovde u pitanju, da li je reč o prognostici, sinhronicitetu, ili nečem trećem, ja, bar za sada, nemam odgovor.

\section{Epilog u e}

Onoga dana (30. januaru 2014), za vreme ručka, zajedno smo postavili pitanje smisla krajnje "deonice“ u brojevnoj sekvenci Đurinog sna: „Dva postaje tri“. Ja sam se prisećao da sam još onda, devedesetih godina prošlog veka, imao nekakvo objašnjenje, kojeg se sada nisam mogao setiti, a nije mi padalo na pamet ni nešto drugo, što bi moglo biti „rešenje“. Jedino što sam mogao da kažem jeste da to može biti u vezi sa činiocima prvog savršenog broja, broja 6: 2 × 3 jednako je 6 .

Međutim, dok smo tako, za ručkom, sedeli i ćaskali, pitao sam se, da li da Đuri predočim i moj najnoviji rezultat o genetskom kodu; pa sam odustao, bilo bi previše, a možda bih i pokvarilo prijatnu atmosferu koja je sve vreme vladala. Rastali smo se, dakle, bez razgovora na tu novu temu.

A, u tom mom najnovijem rezultatu opet su se našli brojevi (broj atoma konstituenata genetskog koda), kao bitnih determinanti. Najkraće rečeno, logička (i hemijska) situacija kojom sam se, u ovom najnovijem periodu mog (40-togodišnjeg) istraživanja GK bavio, bila je sledeća: od 64 kodona, 61 ima aminokiselinsko značenje, te,

${ }^{6}$ Ova analiza mi je pomogla da uvidim da je Homer broj stihova llijade i Odiseje odredio tako što je iz geometrijske progresije $2^{n}(2$ exp $n$ ) uzeo početnih $3 \times 5$ brojeva i iz njih, po ključu ogledalne simetrije (dva broja izabrati, jedan neizabrati, dva izabrati, itd), uzeo one brojeve čiji zbir će dati upravo zbir broja stihova u dva navedena speva. Ali, ono što je iznenađujuće bilo, jeste saznanje, da one brojeve koje nije izabrao Homer, izabrao je Njegoš, i, u cifru tačno, odredio - broj stihova u Gorskom vijencu, plus broj scena, plus broj stranica na kojima je štampan, itd (videti u mojoj knjizi „Njegošev iskonski logos“, tom II, str. 189; uporediti i rezultat 1741630, nađen u GK, zatim kod Homera (str. 191 u ovoj knjizi), kao i kod Njegoša (str. 60). [MMR, 2021, Boxes 13; 13.1 - 13.4.] 
otuda, ima smisla kodonima pridružiti tačno 61 aminokiselinski molekul, onako kako kodoni te aminokiseline i kodiraju. \{Додатна напомена (10. 05. 2021): Те 2014. године говорио сам о „40 година“ свог истраживања; сад понављам исту реченицу. Како? Ствар је у томе што сам се 1974. године пријавио за магистарски рад, а 1981. године сам га одбранио и магистрирао. Четири године касније, 1985, докторирао сам биохемију, па ћу и 2025. године поново говорити о моме 40-годишнјем истраживању.\}

Odavno sam ja (ali i drugi istraživači) izračunao da je ukupan broj atoma u 61 aminokiselinskom molekulu (u njihovim bočnim nizovima), tačno 594. Ako se kodoni (64 kodovne „reči“) poređaju po kriterijumu trećeg, a ne drugog slova u kodonu (kako se do sada isključivo radilo), ${ }^{7}$ tada dolazi i do "razbijanja“ broja 594 na dva dela. U aminokiselinskim molekulima koji se nalaze na levoj (pirimidinskoj) strani Tablice GK ima 288 atoma, a u onima na desnoj (purinskoj) strani - 306 atoma. [MMR, 2017, Table 3.5, p. 10/51.]

Trebalo je sada odgonetnuti - šta je smisao ovih brojeva? Da bi se to moglo, trebalo je poći od činjenice da realno u genetskom kodu ima samo 20 aminokiselinskih molekula, sa 204 atoma u njihovim bočnim nizovima; s druge strane, u 64 kodona genetskog koda ima 192 nukleotida. ... Svi moji pokušaji da dođem do odgovora na postavljeno pitanje pokazali su se bezuspešnim (a odgovor nisam znao ni onog dana dok smo razgovarali za pomenutim ručkom), dok se nisam setio Đurinog sna. Rešenje je tada, samo od sebe, bilo (is)kazato: polovina broja atoma (1/2) u osnovnom skupu aminokiselina iznosi 102, a polovina broja nukleotida (1/2) u skupu 64 kodona iznosi 96. $\mathrm{E}$, sada, ako u tim polovinama „dva prelazi u tri“, dobićemo broj atoma u izvedenom

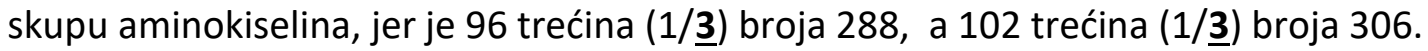

Nakon svega izloženog, ima smisla postaviti pitanje, šta je objektivni (naučni) smisao i razlog ovog odnosa 3:2, nezavisno od Đurinog sna. S jedne strane, to je poznati limit zlatnog preseka, ${ }^{8}$ koji se realizuje upravo preko tog odnosa (3:2). A drugo je odnos ova dva broja u nizu prirodnih brojeva. Naime, svaki sledbenik broja $n$ neminovno se uvećava za $n$-ti deo od $n$. Otuda, jedino u slučaju broja 3, uvećanje je tačno za polovinu prethodnika, što je, s druge strane, uslov za "simetriju u najjednostavnijem slučaju. ${ }^{9}$

Dano u Beogradu, na Dan Sveštenomučenika

Miloje M. Rakočević Klimenta Ohridskog, Leta Gospodnjeg 2014, dana 5. februara, u sred srede!

\footnotetext{
7 U „tekućoj“ nauci o GK smatra se da samo druga i prva pozicija u kodonu poseduju kodirajuću funkciju, dok je treća pozicija, navodno, nekodirajuća. Ako se, međutim, GK posmatra kao sistem, koji je već prebiotski bio kompletan, tada su sve tri pozicije kodovne i kodirajuće. (Tablica GK, po kriterijumu trećeg slova, daje se ovde ....) [MMR, 2017, Tab. 3.5, str. 10/51.]

${ }^{8}$ Moore, G.A. (1994) The limit of the Golden Numbers is 3/2. The Fibonacci Quartely, June-July, 211-217.

${ }^{9}$ Marcus, S (1989) Symmetry in the symplest case: the real line. Computers Math. Applic., 17, 103-115
} 